Kerner, K.F. Different methods of printing transfers for ceramic bases and their ecological aspect. Eurasia: Current Issues of Cultural Heritage. European Scientific e-Journal, 3(3), 53-62. Hlučín-Bobrovníky: "Anisiia Tomanek" OSVČ.

Kerner, K.F. Transfer grafiki na podłoża ceramiczne różne metody i ich ekologiczny aspekt. Eurasia: Current Issues of Cultural Heritage. European Scientific e-Journal, 3(3), 53-62. Hlučín-Bobrovníky: "Anisiia Tomanek” OSVČ.

DOI: $10.47451 /$ her2020-11-001

The paper is published in Crossref, ICI Copernic, BASE, Zenodo, OpenAIRE, LORY, HSLU, J-Gate, Academic Resource Index ResearchBib, ISI International Scientific Indexing, eLibrary, Mendeley, and WebArchive databases.

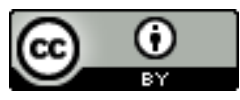

Kimba Frances Kerner, Masters of Art, Doctorate Student, Department of Printmaking, Warsaw Academy of Art. Warsaw, Poland.

\title{
Different methods of printing transfers for ceramic bases and their ecological aspect
}

Abstract: The relevance of this article is the search for new means for artists to pursue their creative visions. Research done within the creative field furthers creativity and allows for new forms of expression. However, despite the singular purpose of creation itself, there remains responsibility. It is crucial that artists also can find ways of avoiding making more hazardous waste for the environment. This particular research is so timely when the whole world is in search of new methods of saving resources. article describes the various methods used for creating ceramic transfers. The second aspect describes the toxicity of certain chemicals used in specific processes. The research proposes the creation of a new method that would be based on the historical transfer method, but using updated techniques to minimize the toxic waste created from currently practiced methods.

Keywords: Staffordshire, Spode, Małgorzata Et Ber Warlikowska, Marek Cecuła, transferware, silk-screen printing, digital ceramic printing, etching, ceramic pigments, matrix, porcelain.

Kimba Frances Kerner, Magister Sztuk Pięknych, Studentka studiów doktoranckich, Wydział Grafiki, Akademia Sztuk Pięknych w Warszawie. Warszawa, Polska.

\section{Transfer grafiki na podłoża ceramiczne różne metody i ich ekologiczny aspekt}

Abstract: Znaczenie tego artykułu polega na poszukiwaniu nowych sposobów realizacji przez artystów ich pomysłów twórczych. Kreatywne badania sprzyjają kreatywności i umożliwiają znajdowanie nowych form wyrazu. Jednak pomimo jedynego celu samego stworzenia, odpowiedzialność pozostaje. Niezbędne jest, aby artyści mogli również znaleźć sposoby na uniknięcie tworzenia bardziej niebezpiecznych odpadów dla środowiska. W artykule opisano różne metody tworzenia transferów ceramicznych. Drugi aspekt opisuje toksyczność niektórych chemikaliów używanych w określonych procesach. W badaniach zaproponowano stworzenie nowej metody, która byłaby oparta na historycznej metodzie transferu, ale z wykorzystaniem zaktualizowanych technik, aby zminimalizować toksyczne odpady powstające z obecnie stosowanych metod.

Stowa klucrowe: Staffordshire, Spode, Małgorzata Et Ber Warlikowska, Marek Cecuła, sitodruk, ceramiczny druk cyfrowy, aquaforta, pigmenty ceramiczne, matryca, porcelana. 


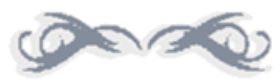

\section{Introduction}

The relevance of this article is the search for new means for artists to pursue their creative visions. Research done within the creative field furthers creativity and allows for new forms of expression. However, despite the singular purpose of creation itself, there remains responsibility. It is crucial that artists can also find ways of avoiding making more hazardous waste for the environment. This particular research is so timely when the whole world is in search of new methods of saving resources.

The transfer of graphics, the image from the graphic matrix to ceramics is not only possible but gives interesting artistic effects without the use of toxic solvents. The idea of exploring and developing a classic process as well as implementing it into the conditions of a modern graphic workshop can expand the workshop of methods that artistic graphics today have. At the same time, this method has many possibilities to create structures and matter resulting from the essence of the graphic matrix. For example, deep etch lines are felt on the porcelain surface also after it has been fired in a ceramic oven shows the huge artistic potential of the subject being studied. This method will not be available for anyone, who does not possess a real printmaking workshop, because the necessary equipment is not easy to acquire and use, but in the academic environment, this could help many students and teachers who want to experiment with new potential methods.

\section{History of transferware and contemporary transfer techniques}

The classic method of transferring graphics to a ceramic base has a history dating back to the mid-eighteenth century. Originally, the method was invented in Italy but was not developed. Factories, which first flourished in England and later in other countries, began transferring paintings and decorations from engraving matrices to porcelain items. The goal of these practices was to prepare larger amounts of decorations for firing. One of the inventors of transferware was John Sadler, an eighteenth-century English printmaker who, based on his observations of children's games, developed a technique that allowed the mass transfer of prints to ceramic plates. The copper plate was meticulously hand engraved with a pattern using a variety of methods (including point stamping, which creates shading and tonal diversity) and tools such as the roulette or engraving cutters that make $\mathrm{V}$-shaped grooves for the pigment to seep into. The engraving depth and accuracy of the line or dot determine the strength of the colour. In the nineteenth century, making a copper plate took several weeks. The finished engraved plate was heated on the stove. The metal oxide (usually cobalt) was mixed with printing oil and was rubbed into the grooves of the metal matrix to ensure a good drawing impression and transfer. The excess of the mixture of prepared ceramic paint was wiped away, due to which the ink/paint remained only in the grooves of the copper plate, as in gravure printing techniques. Then, in the transfer process, a suitable kind of tissue paper, moistened with a soap solution, was applied evenly to the heated copper plate. The tissue paper and plate prepared in this way were passed through a felt-covered press, which pressed the ink onto the tissue paper, after which the plate was placed back on the oven to safely remove the tissue from the matrix. The paper with the 
reflected image (mirror image) was successively placed onto the ceramics, the wrinkles all smoothed out, and then rubbed with stiff bristles so that the print was transferred to the porcelain item. The object thus prepared was placed in a tub with cold water, and the tissue paper was removed without destroying the colour and image. The object was then fired for ten hours at $680-750^{\circ} \mathrm{C}$ so that the oil evaporated first. The ceramic object was then fired a second time at $1050^{\circ} \mathrm{C}$ so that the design turned blue. This method was singularly in use in England until the invention of the water-slide decal, used in conjunction with silk-screens.

With the development of printing techniques, the methods of transferring images to ceramics have undergone numerous transformations. Currently, silk screen printing is practiced. It can be observed that the transfer method using screen printing is the most common method used by artists. In this technique, the printing form is a fine mesh stretched over the frame and covered with a photosensitive emulsion (Figure 1). Preparing it for printing involves making a template, i.e., covering places that will not be printed. The photosensitive emulsion on the mesh is exposed to a UV light in the frame. After developing (rinsing the unexposed emulsion) and drying, the template mesh is ready for printing. The print is created by forcing the paint onto the base with a squeegee. In this process, an image is quickly made; templates are often prepared on the computer. However, screen printing materials that are dedicated to ceramics (paints, fixatives, varnishes) are highly toxic, so working on graphic transfers using this method is practically impossible in the normal conditions of an academic artistic workshop, even though image transfer to ceramics was widely practiced in the $18^{\text {th }}$ and $19^{\text {th }}$ centuries using just a simple printmaking workshop.

Despite the popularity of water-slide decals using the silk-screen technique, the process of making them uses highly toxic chemicals. One of the most important chemical liquids used in screen printing is solvent. Most often, solvents consist of a mixture of acetone (approx. 30\%) and toluene (approx. 70\%). Some manufacturers also use xylene, ethylbenzene, methyl acetate, ethyl acetate, various alcohols, and other additives in their composition. Of those avoided above, toluene is used in the largest amount and is very harmful. Its negative effects can impact the respiratory, circulatory, reproductive, nervous, and immune systems but, above all, the nervous system, which consists largely of tissue rich in lipids in which toluene is soluble. Other harmful substances that are essential to screen printing are the flammable kerosene and turpentine.

The second commonly used method for ceramic transfers is digital printing with ceramic pigments, which also produces water-slide decals (Figure 2). The ceramic decal pattern is precisely developed in a computer program with specialized software and then, using a printer calibrated for a specific set of pigments, transferred to the object for future firing. The range of colours for printing from the CMYK palette gives a wide range of possibilities. The more interesting aspect for an artist's purposes that it is possible to work with colours that have been tested to avoid errors after firing ( $95 \%$ match after firing). Image transfer using a digital printer, like matrix printing, is almost non-toxic. The preparation process takes place quickly due to different parameters. It is a very effective tool, ensuring a wealth of effects and very high predictability of the colours used in the final effect. However, digital printers with ceramic pigments are almost inaccessible for artistic activities because they are not common and their services are very expensive. One of the most important differences in digital printing transfers concerning screen printing transfers is that digital print transfers have a range of tones. With one quick print, you 
can get colour gradations while using the screen-printing method, this effect requires multiple images superimposed. At the same time, the colours applied using a screen or digital printing are different and have both their limitations and unique qualities.

\section{Gravure printing techniques and research methodology}

Classic transfer refers to the 18th-century tradition and research will be based on image acquisition using workshop printmaking techniques. Application tests include optimal printing surfaces (image carriers) for transfer to porcelain. In the preparation of used gravure printing techniques (dry point, etching, aquatint), relief and linocut printing, and flat printing to enable the selection of the most favourable methods for transfers. To this end, we will also examine the effect of matrix thickness $(05,08,1 \mathrm{~mm})$ on the result of the transfer from the selected material (zinc, aluminium, copper, linoleum). An effective method of transferring a graphic image to ceramic bases requires the implementation of tests and conducting to determine recipes and technological processes. Examination and description of the transferred image media, ranging from gravure printing plates to relief printing and anastatic printing. The development of recipes for the composition of graphic-ceramic paints, firing methods, methods of applying the image, the papers used will also form the basis of the research.

The first stage of research will be the analysis of how to set up the matrix for transfer to optimally prepare the most appropriate classic graphic technique as each gives slightly different creative possibilities. In gravure printing techniques, the paint is rubbed into the grooved or etched places which are concave to the surface of the plate. The drawing is prepared with engraving needles, scrapers, roulette. The print is made on rice paper and tracing paper using a graphic press. The beginnings of gravure printing are seen in the technique of the so-called black print, which Italian craftsmen of the first half of the $15^{\text {th }}$ century used to make decorative items made of gold and other metals. The ornament was cut or etched in metal, then the drawing was blackened and reflected on paper to preserve the pattern. The first prints of engraved metal plates appeared in Europe almost simultaneously with the woodcuts. In addition to widespread steel engraving or copper engraving, which offered the possibility of large volumes, the dry needle technique, such as engraving, developed at the same time similar to copper engraving. The drawing in this method is made on the prepared metal matrix. Zinc sheets and aluminium sheets will be used for the tests due to their different values. By properly using the line, you can achieve tonal transitions from very subtle delicate grays to deep blacks. Etching (Latin aquafortis "strong water") will be the next tested technique. The etched technique was invented at the turn of the $15^{\text {th }}$ and $16^{\text {th }}$ centuries. The linearly developed drawing on the surface of the prepared, asphalt-covered metal plate is subjected to etching. The technique allows a very diverse linear drawing to be obtained by etching. Etching seems to be the most optimal technique for using for transfer to ceramics. Nitric acid, ferric chloride, and sodium chloride sulphate will be used in the digestion process. The most environmentally-friendly method is ferric chloride and sodium chloride sulphate. For copperplate etching, 45-degree iron chloride on the Baume scale will be used, while for aluminium etching sodium chloride sulphate solution 75 grams per litre of water. Etching for zinc in nitric acid will take place in a solution with a water concentration of up to 7:1 (after the bath is finished, the solution is neutralized using baking soda.) Tests of graphical transfer media will also include the aquatint technique (incl. Aquatinta coloured water). Aquatint 
was invented in 1768 by Jean-Baptiste Le Prince. The metal plate is sprinkled with powdered rosin and then heated so that the rosin grains melt and stick to the metal surface. (rosin is a resin, of natural origin from conifers. The composition of rosin is $(90 \%)$ a mixture of two isomeric resin acids). In this way, a kind of raster is created that protects the surface of the plate from the action of nitric acid. The technique allows etching to achieve various levels of value.

Further research will cover the technique of relief printing and linocut, whose name comes from the matrix: linoleum, invented in 1863, and very quickly adopted by artists. In this method, the paint is applied from the roller to the surface of the matrix, blackening the convex places that are not engraved, and the concave lines and planes remain white. The drawing is cut with chisels and cutters. However, the effect of this method is different from intaglio printing techniques. Gray gradation is a consequence of the intensity of cut white lines and points that create tonal transitions from black to light grey. The means of the print process ensures that the print is devoid of graphic matter, but has a characteristic relief.

The next tested method will be flat and anastatic printing; a technique derived from lithography used at the turn of the century as a way to duplicate old prints by transferring the image by anastatic reprint to stone for prints. Similarly, to the lithographic stone, wet photocopied paper has anastatic properties: it repels greasy paint that adheres only to places of drawing, like printing toner. Anastatic reprints from a photocopier are made on a gravure printing press. It is a method of transferring the image directly to the matrix or paper/tracing paper. This technique has advantages resulting from the possibility of using photography, but it is also burdened with the specific nature of a simplified image, which is a consequence of the black and white copy from the printer. Prints used in anastatic transfer must be brought to contrast in which subtle grey tones are destroyed. Such a transfer is very easy and fast in the matrix development process, but it becomes characteristically simplified in the image.

The next step will be to develop recipes for modern low-toxic or non-toxic ceramic paints in the basic range of colours dedicated to graphic transfer to ceramics, porcelain, glass. Pigments, fillers, and fixatives will be tested to create a range (6-8 colours) of ceramic glaze paints, intended for decorating ceramics, porcelain, and glass, using transfer techniques from graphic matrices (metal techniques, linocut, anastatic printing). The effects of the developed recipes will be analysed at the Institute of Ceramics and Building Materials. Based on the spectrometer and diffractometer tests, both the intensity of pigments and the colour brightness will be analysed. The criterion for assessing the suitability of the formulas developed for use in the transfer method will be the intensity and colour match after firing following the sampler used in digital printing. The goal of this research will be to achieve optimal results, comparable to digital printing while maintaining the significant advantages of classic transfer, i.e., the unique qualities of the line structure and graphic matter transferred to ceramics.

In Poland today, the subject of graphics transfer to ceramics in the artistic realm is primarily dealt with by Dr. hab. Małgorzata Warlikowska at the Faculty of Graphic Arts and Media Art, in the Academy of Fine Arts in Wrocław. There she performs experiments related to the transfer of graphics to ceramics, using screen printing. I am impressed by the achievements and undertakings of this artist, who, for years, has been discovering various experimental methods of connecting ceramics and printmaking. The screen-printing technique she uses is the fastest and best-known technique for making large quantities of transfer prints. Professor Warlikowska 
is known for her huge installations, which contain dozens of sculptures of various sizes filling gallery spaces. The screen-printing technique is also used in industrial conditions, e.g., in the Ćmielów Design Studio headed by Marek Cecuła. However, when the project requires only a small number of prints, the whole process of screen printing becomes very uncomfortable. Many designs do not require a large number of prints, especially when used for smaller sculptures or conceptual works. In addition, this technique is burdened with high toxicity, which under the conditions of an artistic workshop is a huge drawback. The classic transfer technique, on the other hand, minimises the load to only a few prints. Therefore, the proposed classical method, updated for contemporary use, directly in the academic setting, seems to be very useful in the creative educational process.

Although extremely effective for large projects, the silkscreen technique becomes very uncomfortable when the design does not require a large number of prints or when it is used for smaller sculptures or conceptual works. This technique is also accompanied by the issue of high toxicity that is a disadvantage, even within the conditions of the academic printmaking workshop.

As part of the project, an eighteenth-century method of transferring graphics to ceramics will be developed and adapted to contemporary graphic workshops. The results will be analysed and adapted to the current state of knowledge, submitting to preparations of the matrix (applications from various printing techniques) as well as the method of transfer to ceramics the use of various types of paper, carbon paper, and tissue paper. To this end, it is necessary to research in England, in the area of Stoke on Trent, where there are not simply large historical resources available, but Spode, which is the last factory in the world that used this method of production (until 2009), is located there (owned by Portmeirion Potteries Ltd). Research is planned at the Spode Museum Trust Heritage Centre (where they still do demonstrations of the original transfer technique with period materials) and secondary research will be carried out at The Potteries Museum and Art Gallery (Stoke-on-Trent) and Victoria and Albert Museum in London - where they house the largest collection ceramics collections in the world, including some of the first transfers ever created. Research in the field of the arts is specific. It is essentially for use within the creative process and experiments in its dimension. The goal of these activities is primarily to search for a new path for the expression of creators. The knowledge acquired through the study of materials, technological processes, and relationships between them are meant to, first of all, broaden the artist's tool workshop and, due to the availability of new functions of expression, better formulate the message for the recipient.

\section{Conclusion}

In conclusion, both the classic method of transfer from a metal matrix, linocut and silkscreen or digital printing have potential that can be studied and described for future users of these methods. Artistic and technological activities in the field of graphics transfer to ceramics have not been developed so far in Polish. At the same time, I have a deep conviction that the concept of combining the old methods of print transfers to ceramics with new technologies is an innovative scientific study worth pursuing, for the sake of academic progression in the field of printmaking. 


\section{References:}

Burnett, J.B. (2015). Graphic Clay: Ceramic surfaces and Printed Image Transfer. Lark Crafts.

Catafel, J., Oliva, C. (2004). Techniki Graficzne.Warsaw: Arkady.

Coldwell, P. (2010). Printmaking a contemporary perspective. London: Black Dog Publishing Ltd.

Divis, J. (1984). Porcelana Europejska. Warsaw: Wydawnictwo Artystyczne i Filmowe.

Hildyard, R. (2009). European Ceramics. South Kensington London: V\&A Publishing Victoria and Albert Museum.

Petrie, K. (2011). Ceramic Transfer Printing. American Ceramic Society.

Savage, G. (1963). Porcelain through the Ages. Penguin Books Ltd.

Szkurłat, A. (2011). Manufaktura Porcelany i Fajansu w Korcu. Warsaw: ArxRegia, Zamek Królewski w Warszawie.

Turner, W. (1907). Transfer Printing on Enamels, Porcelain and Pottery. London: Chapman and Hall, Ltd.

Wandless, P. A. (2013a). Image Transfer on Clay. Sterling Publishing.

Wandless, P. A. (2013b). 500 prints on Clay: An Inspiring Collection of Image Transfer Work. Lark Crafts.

Warlikowska, M. et ber. (2014). Mycie twarzy, Jedzac Marlin Monroe (exbibit catalogue). Wrocław: BWA Wrocław, ASP Wrocław.

Warlikowska, M. et ber. (2019). Autoreferat. Wrocław: ASP Wrocław. 


\section{Appendix}

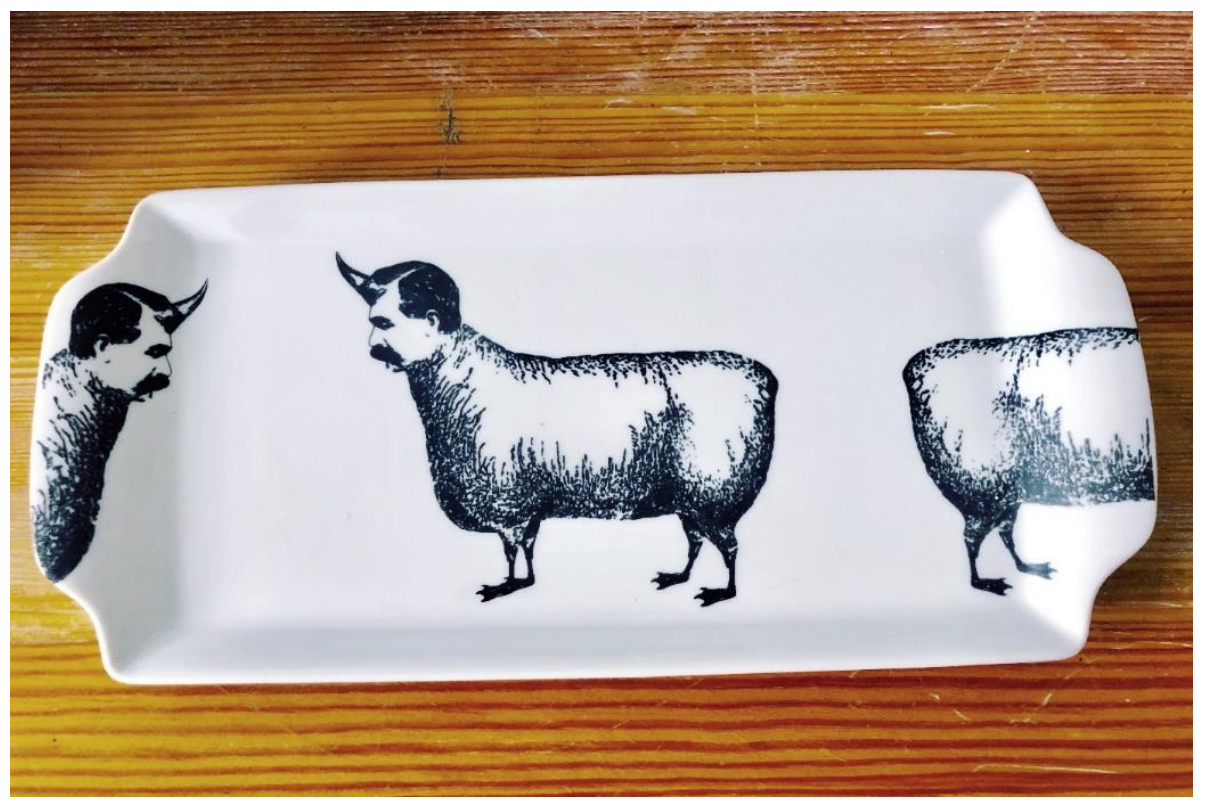

Figure1. Silk screen technique example by Kimba Frances Kerner

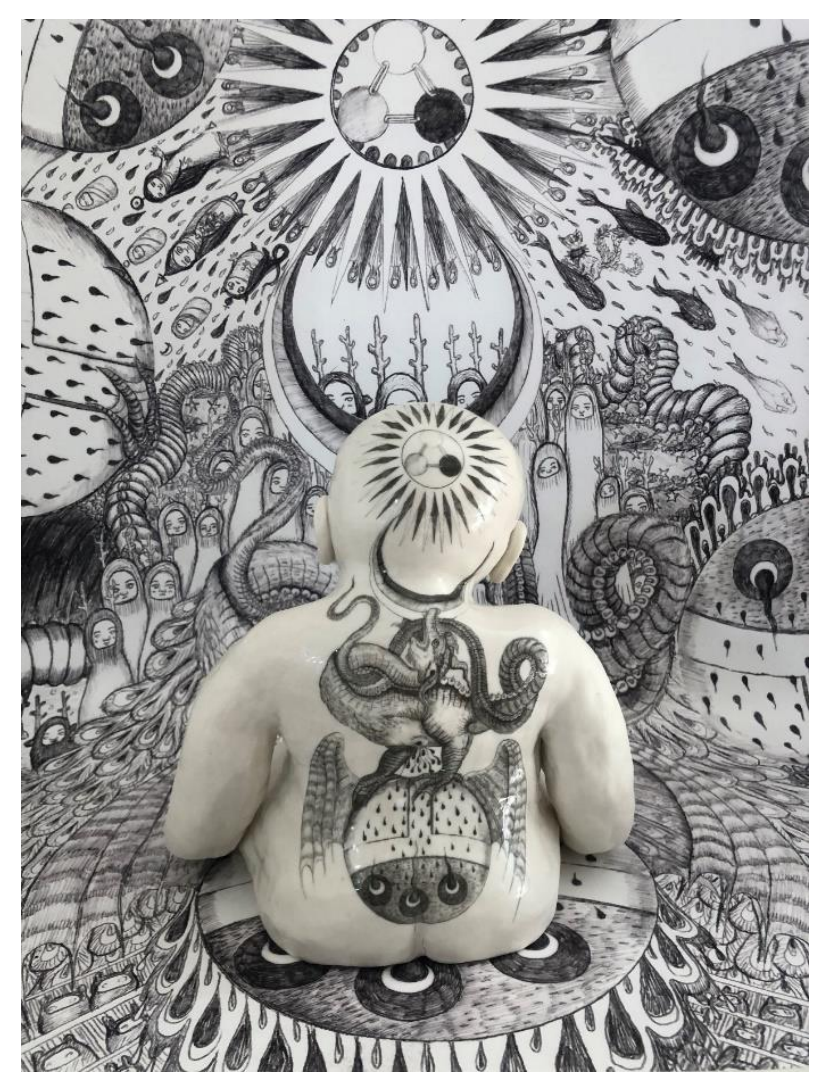

Figure 2. Digital ceramic printing technique example by Kimba Frances Kerner 